Goldschmidt 2021 Abstract

https://doi.org/10.7185/gold2021.4563

\section{Experimental and Modeling Study of Interactions of Rare Earth Elements (REE) Pr(III) and Nd(III) with Citrate and Oxalate: Implications to the Mobility of Actinides and REE and Their Extractions}

\author{
YONGLIANG XIONG ${ }^{1}$, YIFENG WANG ${ }^{1}$, GUANGPING \\ $\mathrm{XU}^{2}$ AND SARA RUSSO ${ }^{1}$ \\ ${ }^{1}$ Sandia National Labs \\ ${ }^{2}$ Sandia National Lab \\ Presenting Author: yxiong@sandia.gov
}

The knowledge of the interactions of rare earth elements (REE) and actinides with both oxalate and citrate at the same time is important to many fields. In the nuclear waste management, actinides are co-present with oxalate and citrate in waste streams in some geological repositories. In the surface environments of the Earth, both oxalate and citrate are naturally present along with REE. In the industrial processes, actinides and REE are usually precipitated as their respective oxalates. Citric acid, because of its environmentally friendly nature, may be used for further purification/separation. However, the ternary interactions among actinides/REE, oxalate, and citrate have not been investigated before. In this study, we investigate such ternary interactions via solubility measurements. We use $\mathrm{Pr}_{2}\left(\mathrm{C}_{2} \mathrm{O}_{4}\right)_{3} \cdot 10 \mathrm{H}_{2} \mathrm{O}$ and $\mathrm{Nd}_{2}\left(\mathrm{C}_{2} \mathrm{O}_{4}\right)_{3} \cdot 10 \mathrm{H}_{2} \mathrm{O}$ as the solubilitycontrolling phases for the solubility measurements in citric acid solutions. The solid phases, $\operatorname{Pr}_{2}\left(\mathrm{C}_{2} \mathrm{O}_{4}\right)_{3} \bullet 10 \mathrm{H}_{2} \mathrm{O}$ and $\mathrm{Nd}_{2}\left(\mathrm{C}_{2} \mathrm{O}_{4}\right)_{3} \cdot 10 \mathrm{H}_{2} \mathrm{O}$, provide the sources for both REE and oxalate. In addition, we use $\operatorname{Pr}_{2}\left(\mathrm{C}_{2} \mathrm{O}_{4}\right)_{3} \cdot 10 \mathrm{H}_{2} \mathrm{O}$ and $\mathrm{Nd}_{2}\left(\mathrm{C}_{2} \mathrm{O}_{4}\right)_{3} \cdot 10 \mathrm{H}_{2} \mathrm{O}$ as the respective analogs to $\mathrm{Pu}_{2}\left(\mathrm{C}_{2} \mathrm{O}_{4}\right)_{3} \cdot 10 \mathrm{H}_{2} \mathrm{O}$ and $\mathrm{Am}_{2}\left(\mathrm{C}_{2} \mathrm{O}_{4}\right)_{3} \cdot 10 \mathrm{H}_{2} \mathrm{O}$.

Our experiments indicate that the solubilities of $\mathrm{Pr}_{2}\left(\mathrm{C}_{2} \mathrm{O}_{4}\right)_{3} \cdot 10 \mathrm{H}_{2} \mathrm{O}$ and $\mathrm{Nd}_{2}\left(\mathrm{C}_{2} \mathrm{O}_{4}\right)_{3} \cdot 10 \mathrm{H}_{2} \mathrm{O}$ are much higher than those predicted with the model including all of the respective aqueous binary complexes of REE with oxalate and citrate [1-3]. This suggests that the ternary complexes should be required. We find out the model incorporating the 1:1:1 ternary complexes (e.g., $\operatorname{Pr}\left(\mathrm{C}_{2} \mathrm{O}_{4}\right)\left(\mathrm{C}_{6} \mathrm{H}_{5} \mathrm{O}_{7}\right)^{2-}$, and $\mathrm{Nd}\left(\mathrm{C}_{2} \mathrm{O}_{4}\right)\left(\mathrm{C}_{6} \mathrm{H}_{5} \mathrm{O}_{7}\right)^{2-}$ ) excellently fits our experimental data. These findings have important applications to many fields.

Acknowledgements: Sandia National Laboratories is a multimission laboratory operated by National Technology and Engineering Solutions of Sandia, LLC., a wholly owned subsidiary of Honeywell International, Inc., for the U.S. Department of Energy's National Nuclear Security Administration under contract DE-NA-0003525. SAND20211907A. This research is funded by the SFWST programs administered by the Office of Nuclear Energy (NE) of the U.S. Department of Energy, and Sandia National Laboratories LDRD.

1. Thakur, P., Xiong, Y., Borkowski, M. and Choppin, G.R., 2012. Radiochimica Acta, 100, pp.165-172.

2. Thakur, P., Xiong, Y. and Borkowski, M., 2015.
Chemical Geology, 413, pp.7-17.

3. Hummel, W., Anderegg, G., Puigdomènech, I., Rao, L. and Tochiyama, O., 2005. Radiochimica Acta, 93, pp.719-725. 